\title{
ADOLESCENT PEER MENTORING ON REPRODUCTIVE HEALTH IN ACHIEVING SUSTAINABLE DEVELOPMENT GOALS 3
}

\author{
Arin FITHRIANA* and Rendy Putera KUSUMA \\ Budi Luhur University, Indonesia \\ *arin.fithriana@budiluhur.ac.id
}

\begin{abstract}
Adolescence is a transitional age to shape and find an identity. So sometimes teenagers try many things including doing new things that violate ethics and relationships. This is partly due to misunderstanding and ignorance about the scope and importance of reproductive health. Some cases related to reproductive health are caused by curiosity, wanting to try, or being invited by friends. Mistakes in taking along and interacting encourage cases related to reproductive health such as early pregnancy, abortion, cervical cancer, and being infected with sexually transmitted diseases. Therefore, it is necessary to take preemptive or preventive action against attitudes and behaviors that have the potential to cause unrest in the community. The implementation of this community development is in partnership with the administrator of RT.09/RW.03 Kelurahan Cilangkap, East Jakarta by carrying out educational activities in the form of Training for Adolescent Reproductive Health Counselors "Peer Mentoring" in Achieving Sustainable Development Goals 3. This activity emphasizes understanding and ethics in maintaining reproductive health considering that adolescents are the next generation. Without understanding and ethics, teenagers will be easily tempted by relationships that do not fit the norm. Participants in this activity are male youth members of the youth organization. This scope is made to facilitate communication and discussion related to reproductive health which is still considered taboo. The implementation of the activity is carried out in three stages involving partners. Meanwhile, the methods used are educational methods, question, and answer, and group discussion forums. As for evaluation, there are four stages to achieving and sustaining activities, such as understanding the material, redescription through question and answer, reexplaining by discussing cases through group discussion forums as well as forming peer groups, and evaluating the understanding through questioner.
\end{abstract}

Keywords: reproductive health, youth, Sustainable Development Goals 3

\section{BACKGROUND}

Reproductive health generally is understood as health in the reproductive organs. Reproductive health is also considered a discussion for adults or those who are married. There is a narrowing understanding of reproductive health that only pays attention to the physical or biological conditions of the reproductive organs. Even talking about reproduction and health is often considered taboo by some people, so that when faced with problems related to reproduction, someone is reluctant to talk about it and even keeps it from getting worse. One of the reasons is the existence of a taboo or shameful stigma. Even when someone tries to talk about it with other people, it turns out to be the subject of ridicule. Especially true for teenagers. So, there is a tendency to shut down or seek answers from other media. The existence of this tendency encourages to provide socialization or understanding of reproductive health for adolescents.

Another thing is that the existence of information and massive technological developments are difficult to stem and even limit all forms of information received. Information in digital form, whether film, drama, tiktok, or just an image display is easily accepted and distributed. Including values and culture in interacting with the opposite sex. Unwittingly, this condition contributes psychologically to the development and understanding of reproduction. The existence of abortion, early marriage, and venereal disease are part of the negative impact of getting along and technological developments related to the understanding of reproductive organs. This error in understanding is not only physical damage but also psychological which has an impact on prolonged trauma.

Indonesian Demographic and Health Survey (IDHS) 2017, especially those related to adolescent reproductive health, show that dating behavior is an entry point for risky behavior practices that make adolescents vulnerable to pregnancy at an early age, pregnancy out of wedlock, unwanted pregnancy, and infection, sexually transmitted diseases to unsafe abortion. The survey showed that the majority of teenage girls (81\%) and teenage boys (84\%) were in a relationship. Forty-five percent of girls and 44 percent of boys start dating at the age of 15-17. Most of the girls and boys admitted that when they were dating they held hands (64\% of women and $75 \%$ of men), hugging (17\% women and 33\% men), kissing lips (30\% women and $50 \%$ men) and touching/touching. (5\% women and $22 \%$ men) (bkkbn.go.id). Although 99 percent of women and 98 percent of men think that virginity needs to be maintained, there are 8 percent of men and 2 percent of women who report having sexual relations, for reasons including: 47 percent love each other, 30 percent are curious, 16 percent happen just like that, 3 percent they were coerced and influenced by friends. Among women and men who had premarital sex, 59 percent of women and 74 percent of men reported having first sexual intercourse at age 15-19. Among women and men, 12 
percent of unwanted pregnancies were reported by women and 7 percent were reported by men who had partners with unwanted pregnancies. Twenty-three percent of women and 19 percent of men knew a friend they knew had an abortion, one percent of them accompanied/influenced a friend/someone to have an abortion. This condition places teenagers as actors who are vulnerable to the health of their production.

The definition of reproductive health has been regulated in the Republic of Indonesia Law Number 36 of 2009 concerning Health, which is a state of complete physical, mental and social health, not merely free from disease or disability related to reproductive systems, functions, and processes in wome, boy and girl. The government's seriousness in handling of reproductive health problems is also expressed through other policies, such as Government Regulation Number 61 of 2014 concerning Reproductive Health, which guarantees the fulfillment of reproductive health rights for everyone and guarantees maternal health in reproductive age so as to give birth to a healthy generation and reduce maternal mortality.

Indonesia has signed the agreement of the International Conference on Population and Development (ICPD) in Cairo in 1994. The conference agreed on a paradigm shift in managing population and development issues by prioritizing health services for the fulfillment of individual reproductive rights, both for males and females, throughout their life cycle. The scope of reproductive health according to ICPD includes 10 things, namely: 1) maternal and newborn health, 2) family planning, 3) infertility prevention and treatment, 4) prevention and management of miscarriage complications, 5) infection prevention and treatment Reproductive Tract (ISR), Sexually Transmitted Infections (STI), and HIV AIDS, 6) sexual health, 7) sexual violence, 8) early detection of breast cancer and cervical cancer, 9) adolescent reproductive health, and 10) advanced reproductive health age and prevention of harmful practices such as Female Genital Mutilation (FGM) (Kemkes.go.id)

Meanwhile, according to IDAI (Indonesian Pediatric Society), adolescent reproductive health is not only related to sex but also relates to the physical, mental, and even social conditions of adolescents themselves. Teenagers have a high curiosity and tend to want to try new things, whatever it is, without thinking about the risks. Not infrequently this becomes a reproductive health problem. In fact, most teenagers lack awareness of the consequences of free sex. In fact, by having free sex, our reproductive health is at stake, such as risking unwanted pregnancies, contracting venereal diseases, contracting HIV/AIDS, and so on. IDAI also noted, it is estimated that $20-25 \%$ of all HIV infections in the world occur in adolescents. Similarly, the incidence of STIs (sexually transmitted infections) is highest in adolescents, especially girls aged 15 years and over.
This community development program partner is a community group RT.09/RW.03 Cilangkap, Cipayung, East Jakarta. In this case, it is the RT (Rukun Tetangga) administrator. RT regarding on the Minister of HomeAffairs Regulation of the Republic of Indonesia (Permendagri) Number 18 of 2018 concerning Village Community Institutions and Village Traditional Institutions is part of the Village Community Institution (LKD) with several tasks and functions such as empowering the community, improving family welfare and improving the quality of resources. human (Permendagri).

One of the things that are the focus of attention on the implementation of community development is reproductive health. Environmental support is needed before problems occur in adolescents in their association. Prevention through understanding reproductive health as the basis for achieving sustainable development (SDGs) 3 on good health and well-being. One of these preventions is by providing training for Adolescent Reproductive health counselors through "Peer Mentoring" in Achieving Sustainable Development Goals 3 at RT.09/RW.03, Cilangkap East Jakarta. This activity is to build a correct understanding of reproductive health. Based on this, preventive actions are the focus of problems that need attention based on surveys and agreements with partners in accordance with the duties and functions of Rt as the administrator of the smallest area in the environment.

\section{METHODS}

The implementation of this activity is carried out in three stages involving the participation of partners, such as; Initial stage, partners participation is providing information on problems faced by partners, giving permission to the team, and signing the Letter of Application and Cooperation. In the Implementation stage, partners' participation is attending and supervising the course activities, conducting evaluations based on quiz results, accompanied by a team, and monitoring evaluation results. Meanwhile, in the Final Stage, partners provide permits to monitor the sustainability of program implementation. Based on these stages, the methods used in this activity include:

1. Provide education on reproductive health to create an understanding of the scope and importance of reproductive health for adolescents as the next generation and support the achievement of SDGs 3 . This activity is carried out by monologue

2. Emphasize the importance of ethics in socializing and interacting according to the provisions to avoid sex and promiscuity, to avoid reproductive health problems that harm oneself and the environment, and even death. This activity is carried out through discussion, question, and answer

3. Formation of peer mentoring groups in a targeted manner to obtain correct information and understanding about reproductive health. This effort is in accordance 
with the duties and functions of $\mathrm{Rt}$ as the administrator of the smallest area in the environment.

This community development invited competent academicians to support, and advice related to the subject. She is Mrs. Hirfa Turahmi, SPd., SST., MKM, a lecturer of the D3 Midwifery Study Program, Faculty of Medicine and Health (FKK) Universitas Muhammadiyah Jakarta (UMJ).

\section{RESULTS AND DISCUSSION}

The activity was held on Sunday, August 09, 2020, at the residents' hall Jl. Persada Kencana IV RT.09/ RW.03 Cilangkap, Cipayung, East Jakarta. The results of the activities are described based on the output targets which are the ultimate goal of the Training for Adolescent Reproductive Health Counselors Cadre "Peer Mentoring" in Achieving Sustainable Development Goals 3, which is to create an understanding of the importance of maintaining reproductive health, which is not only physical but also mental. This understanding also concerns how to interact by paying attention to social ethics, including the use of social media which can influence views in attitudes and behavior that affect reproductive health. Taboo views on reproductive health tend adolescents reluctant or embarrassed to express or ask questions about reproductive health, even with family or close friends. The existence of a response that is considered impolite, embarrassing, and even not age-appropriate post-reproductive health problems is taboo. However, refer to the current reality, especially with the development of information technology that can easily be imitated or even become an example and reference for teenagers, so reproductive health education is important. The type of relationship, especially the opposite sex, which is shown through the media of information and communication is not all appropriate and positive. For this reason, pre-emptive or preventive actions are needed. So those adolescents have a stronghold in understanding reproductive health correctly. Likewise, with the use of information and communication media to obtain information related to reproductive health, assistance is also needed so that it does not become a boomerang for teenagers. Therefore, the activities in the form of training cadres of counselors are one of the solutions in assistance to obtain appropriate and targeted information and media related to reproductive health.

Relationships, environment, and technological developments are unavoidable. Information related to pornography or pornography related to reproduction. Unconsciously, it will affect mental health in reproductive health. This is also the emphasis on delivering community development material. This means that social ethics and the use of information media are also ways to maintain reproductive health. Because reproductive health is not only the physical health of the reproductive organs, but also mental health which affects the application and attitude in maintaining reproductive health. This understanding is also in line with the curriculum and learning delivered in schools from the elementary or equivalent level to high school or the equivalent. For example, the discussion about human reproduction and puberty has been conveyed in school material, not about pornography. Submission in such a way is expected to be a lesson and knowledge in attitude towards reproduction. Likewise, with the material presented at this activity, it is also hoped that teenagers will increasingly realize the importance of reproductive health.

Sometimes, teenagers who tell their experiences related to reproduction such as wet dreams become the object of ridicule among teenagers. So that, some of the teenagers hide what they are experiencing even though there are many questions to be asked regarding the conditions. To avoid ridicule, some teenagers try to find answers on the internet. In this condition, it should be noted that not all information exposed on the internet can be easily digested and understood by teenagers. This is a concern because it is possible that through the internet, teenagers find things related to pornography when looking for answers to what is experienced in their reproduction. This is also a concern in understanding reproductive health. Errors in understanding or ignorance of reproductive health have an impact on the loss of themselves and others.

The material activity begins with an introduction to what is called reproduction and reproductive health. Although it has been taught in schools, it does not specifically discuss reproductive health. This can be seen when asked about what is called reproductive health, not one participant answered. The explanation is continued by defining reproductive health related to individual conditions. the simplest thing in maintaining reproductive health is to keep the reproductive organs clean. Although it sounds taboo, the team explained the importance of keeping the reproductive organs clean, in this case, the genitals. Changes and conditions of the genitals are important to note and keep clean, including after urinating, defecating, and wearing clean underwear. This hygiene is also related to the cleanliness of other limbs including the hands used to clean the reproductive organs. Likewise, when entering puberty marked by dreams, the health and cleanliness of the reproductive organs must be more guarded. Although the urge is natural, it must be maintained, including in interacting with the opposite sex or during. This is because errors in treating reproductive organs will result in undesirable things and will harm themselves and others. This can be seen in the presence of promiscuity, abortion, or early marriage and contracting venereal diseases and even HIV/AIDS. This means that natural impulses must be regulated as well as possible. Therefore, reproductive health is also related to mental health. Regulating emotions and desires is part of reproductive health.

As mentioned before that sometimes teenagers try to find answers on their own, it would be better to talk to their parents. If there are still problems, they can be submitted to 
the counseling teacher. Because this is normal and natural, it is better for teenagers not to ridicule or even bully friends who ask about reproductive conditions and development. Scorn and even bullying will only make the condition worse and will interfere not only with physical health but also psychologically. Therefore, this activity aims to form a cadre of counselors for peers related to reproductive health. Participants are expected to be able to provide positive information related to reproductive health. Of course, this training activity is an initial activity that requires follow-up. Participants who have gained knowledge and understanding about reproductive health can convey information about the importance of reproductive health and emphasize that knowledge about reproductive health is not a taboo subject, but it is important to pay attention to it from an early age to achieve sustainable health.

To find out the participants' understanding, a short question and answer session related to reproductive health was conducted. Questions and answers regarding the right or wrong thing to do regarding reproductive health. As an example:

1. Change underwear once a day (True / False)

2. Washing hands with soap after defecating and urinating (True / False)

3. Wearing tights (True/False)

4. Being alone with the opposite sex in a closed room (True / False)

5. Exercise with friends (True / False)

6. Viewing indecent images (True/False)

7. Opening adult sites (True/False)

8. Asking parents to accompany when opening the internet (True / False)

9. Sharing adult pictures (True/False)

10. Harassing a friend (True/False)

In general, participants are aware of and understand the importance of reproductive health. In this activity, although no special questionnaire was made, considering the situation and conditions were still in the pandemic period. In addition, because the team and academician live in the same environment, they provide opportunities for participants for counseling or further inquires related to reproductive health. This is also part of the sustainability of community development activities.

\section{CONCLUSION}

In adolescents, the search for identity becomes risky if they do not get appropriate assistance and direction, including those related to reproductive health. Talks about reproductive health which are considered taboo make teenagers sometimes do not have the right footing. Training of peer reproductive health counselor cadres is one of the solutions to facilitate adolescents to answer reproductive problems. Collaborating with RT (Rukun Tetangga) is expected to support the achievement of activity objectives. Reproductive health materials that were little discussed in schools were developed in the materials presented at the activities. So that this activity synergies between schools, RT, and the university's team. This community development activity also supports the duties and functions of the RT in maintaining order, improving the quality of citizens, and prospering residents. Likewise, the university team can play more roles in the community, especially in achieving the 3rd sustainable development goal on public health and welfare.

To support the government in achieving SDGs 3, synergy from various parties is needed. That reproductive health is not only a problem for adults, but also an important concern for adolescents. Reproductive health is not only the physical health of reproductive organs but also psychological support. Reproductive health is also not a monopoly of women, but also of men who also play a role in reproduction. The most important thing is that talking about reproductive health is not a taboo subject. Therefore, it is important for adolescents to know and understand reproductive health from an early age. Appropriate and directed counseling is needed and positively provides an understanding of the importance of reproductive health. Even though Budi Luhur University does not have a Faculty of Health, it does not mean that it cannot play a role in the health sector. Cross-sectoral and multidimensional collaboration is important in the real manifestation of the role of higher education in society.

\section{REFERENCES}

Nurhasanah, A. (2016). Psikologi Remaja: karakteristik dan Permasalahannya. Accessed from https://www. kompasiana.com/an/5719c1f41a7b61dc05c50cd9/ psikologi-remaja-karakteristik-danpermasalahannya?page=all.

Untari, PH. (2018). Pengguna Internet Indonesia Paling Banyak di Usia 15 - 19 tahun. Accessed from https://techno.okezone.com/ $\mathrm{read} / 2019 / 05 / 21 / 207 / 2058544 / 2018$-penggunainternet-indonesia-paling-banyak-di-usia-15-19-tahun.

Ariyanti, H. (2018). 90 Persen Anak Muda di Indonesia Gunkan Internet Untuk Media Sosial. Accessed from https://www.merdeka.com/peristiwa/90-persen-anakmuda-di-indonesia-gunakan-internet-untuk-mediasosial.html on 31 March 2018, 22:24 (GMT+7).

Dahono, Y. (2018). Saat remaja Tak Bisa Kendalikan Diri di Media Sosial. Accessed from https://www. beritasatu.com/nasional/550691/saat-remaja-takbisa-kendalikan-diri-di-media-sosial on 25 April 2019, 12:46 (GMT+7).

Awak, U. (2014). Fungsi Sekolah Terhadap Peserta Didik, diakses dari https://www.matrapendidikan. com/2014/09/fungsi-sekolah-terhadap-pesertadidik.html.

Gunarsa, D. and Gunarsa.(1989). Psikologi Perkembangan Anak Dan Remaja. PT. BPK Gunung Mulia, Jakarta. 